https://doi.org/10.52837/27382702-2021-34.2-12

\title{
THE TRANSFORMATION OF THE IRANIAN CHARSHANBE SURI FESTIVAL IN THE YEZIDI TRADITION*
}

\author{
Tereza Amryan
}

\begin{abstract}
The aim of this article is to clarify the transformation of the Iranian Charshanbe Suri festival in the Yezidi religious system. Charshanbe Suri is celebrated on the eve of the last Wednesday before the Iranian New year - Nōwrūz. It is considered to be the point of transition between the old and new years and is associated with cleansing and purifying. Yezidis celebrate Charshama Sor on the first Wednesday after April 13 (according to the Gregorian Calendar). Unlike Charshanbe Suri, Charshama Sor is not considered a transition between the old and new years. Charshama Sor symbolizes the awakening of nature, the arrival of Spring, the New Year, as well as cosmogony, the creation and renewal of the world, and the "birth" of one of the Yezidi saints, Tausi Malak.

There is no doubt that the Yezidi Charshama Sor is a version of the Iranian Charshanbe Suri. This study of Charshama Sor reveals that the Yezidi tradition has preserved Charshanbe Suri and its main symbols but has also endowed it with new, Yezidi interpretations.
\end{abstract}

Keywords: Yezidi, religious, New Year, symbol, Tausi Malak, interpretation, Lalish, Iranian, transformation.

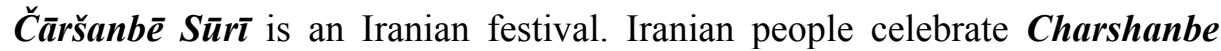
Suri on the eve of the last Wednesday before Iranian New year - Nowruz. Iranians clean their houses, gather outside, set fires, and jump over them. The Charshanbeh Suri festival is somehow one of the steps of cleansing and purifying before the New Year ${ }^{1}$. The Iranian Charshanbe Suri is often called the festival of fire. The name of the holiday is interpreted as either "the Scarlet Wednesday" or "Red Wednesday". The color red symbolizes the color of fire and health'.

Čă religious holidays. Unlike Charshanbe Suri, Charshama Sor is not considered to be the transition period between the old and new years. Yezidis ${ }^{3}$ celebrate

\footnotetext{
${ }^{*}$ The article was submitted on November 1, 2021. The article was reviewed on November 14, 2021.

${ }^{1}$ Raghebi 2021: https://www.visitouriran.com/blog/charshanbeh-soori-a-preparation-for-nowruz/ (accessed 04.11.2021)

${ }^{2}$ Alison 2013: https://www.dailycal.org/2013/03/13/persian-fire-jumping-festival-delightsberkeley-residents/ (accessed 06.11.2021); Baratzadeh 2021: https://kitchenstarts.com/chaharshanbesuri-persian-fire-festival/ (accessed 06.11.2021).

${ }^{3}$ The Yezidi community is one of the biggest national minorities in Armenia. The Yezidis speak an Iranian language. The cradle of the Yezidi religion is Lalish (Gelîyê Lalişê; lit. "canyon/gorge of
} 
Charshama Sor on the first Wednesday after April 13 (according to the Gregorian Calendar). Charshama Sor is especially popular among the Yezidis of Iraq ${ }^{4}$.

Charshama Sor primarily symbolizes the awakening of nature, the arrival of Spring, and the New Year. On the eve of this holiday, the attendants of the sanctuary of Sheikh Adi bring tulips from the mountains and decorate the sanctuaries with them. Yezidis paint eggs ${ }^{5}$ and bake festive biscuits. In the evening, people dance near the sanctuary, light bonfires, and put lamps or wicks on the walls of holy places all over the gorge of Lalish. Yezidis in Iraq prefer to celebrate Charshama Sor in nature. Very often they go to the fields and eat dinner. They throw eggshells and crumbs of the bread in the field ${ }^{6}$, believing that this will make the soil fertile, and the new year will be abundant ${ }^{7}$. The custom of sprinkling leftovers of food in the field during or after a holiday was also widespread among Armenians. For example, it was customary for the people of Artsakh to cook milk soup for during the feast of the Ascension and distribute it to people like a sacrifice (matagh) or sprinkle it in the fields ${ }^{8}$. In Yezidi religious lore, the egg symbolizes the world or the Universe. The egg is sometimes called "the yeast of the universe" and the yolk is compared to the Sun. According to one of the Yezidi cosmogonic

Lalish"), which is situated in the territory of present-day Northern Iraq. The Yezidi community was formed on the basis of a Sufi brotherhood called Adawwiya. It was founded by the Sufi leader Sheikh Adi bin Musafir. After the death of Sheykh Adi and his burial at Lalish, it became the central pilgrimage site and religious center for the Yezidi people. The religious doctrine of the Adawwiya Sufi brotherhood became the basis for the Yezidi religion. The religion of the Yezidis was later also influenced by local beliefs and by different religious streams of the region, and as a result it became a syncretic religion. (Kreyenbroek 1995: 3-6; Arakelova 2010: 6-7, 16) Yezidis were often persecuted, tortured, massacred by their Muslim neighbours, because outsiders misunderstood and misinterpreted the Yezidi religion and called Yezidis "Devil-worshippers". Over time some groups of Yezidi people left Lalish and settled in Sinjar, which became their second center (Parry 1895: 257-

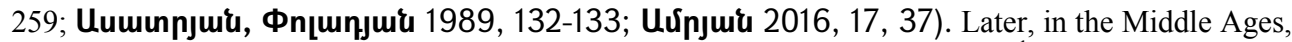
Yezidis migrated and settled in Kars, Van, Igdir, and Surmalu. In the $19^{\text {th }}$ century and in the beginning of the $20^{\text {th }}$ century (after World War I and the Armenian Genocide) various Yezidi groups settled in the territory of the present-day Republic of Armenia (Uরupjur 2016, 14).

${ }^{4}$ Rodziewicz 2016: 347-367.

${ }^{5}$ There is a custom to paint eggs among Zoroastrian people too (Boyce 1977: 42, 170-171).

${ }^{6}$ Nasri 2019: https://www.rudaw.net/english/kurdistan/160420191 (accessed 02.11.2021).

${ }^{7}$ Uúpuui 2016, 243:

${ }^{8}$ Kharatyan 2009: 16. 
myths ${ }^{1}$ God created the world from a pearl ${ }^{2}$. This is mentioned in one of the Yezidi religious hymns ${ }^{3}$ :

Padşê min ev dinya çêkir ji dur û cawhere,

Sipartîye her hevt melekê her û here,

Taûsî Melek li ser kire pîr û serwer e. ${ }^{4}$

My king (my Lord) created this world from the pearl and jewel, $[\mathrm{He}]$ gave it to seven noble angels, And made Tausi Malak ${ }^{5}$ leader over them.

In some Yezidi religious hymns, sometimes an egg is mentioned instead of a pearl. For example:

Padşayê min yî xebîre vê rayê

Erşek afirandibû wê dinyayê,

Cewahir dabû ji beyzayê. (Qewlê Texta) ${ }^{6}$

My King is wise,

He created heaven,

He took out the jewel from inside the egg.

${ }^{1}$ Yezidi religion is of an oral nature. Thus, it is not strange that there are different myths about cosmogony and eschatology in religious lore.

${ }^{2}$ Before becoming a religious, esoteric symbol, associated with magic and medicine, and before being endowed with aesthetic and material value, the pearl was a symbol of cosmogony. The pearl in the shell can also be the symbol of the center of the cosmogony. In the folk tradition and poetry of Iranian peoples, the pearl symbolizes justice, cleanliness, virginity, chastity, and maidenhood. In Sufism and some esoteric teachings, the pearl is used as a symbol of knowledge, percieving wisdom, and the birth of the soul (Uúnjuu 2016, 62-65).

${ }^{3}$ The Yezidi religious hymns (called qawlūbayt) are verse texts that are considered to be sacred. Different religious hymns are dedicated to the Yezidi saints, prophets, creation of the world, the Resurrection, etc. Hymns are recited during various religious ceremonies by Yezidi priests - sheikhs and pirs - and have their unique place in the Yezidi religious system. The religious hymns are in the mother tongue of the Yezidis. The language of religious hymns is quite complicated, full of Arabic loan words and rich with Sufi elements (Uúnjuư 2016, 21, 169-176)

${ }^{4}$ Uúnjư 2016, 36:

${ }^{5}$ In the religious perceptions of the Yezidi people, the essence of God is expressed through three main saints: Sheikh Adi, Sultan Yezid and Tausi Malak. These three saints are considered to be from the nature/essence of God (Arakelova 2005: 198; Uumunnumu, Фnцunjuiu 1989, 133) (Asatrian, Arakelova 2003: 7; Arakelova 2004: 25). Tausi Malak (Peacock Angel) is one of the most important saints of the Yezidi religion. Tausi Malak is considered to have the form of a peacock. In Yezidi folk tradition this is said about Tausi Malak: "Xudê Melekê Taûs ji xwe cuda kirye" (lit. "God has created Tausi Malak from from his own essence.”) (Uরunju⿺ 2016, 35)?

${ }^{6}$ Uúnjuí 2016, 62: 
Charshama Sor secondly symbolizes cosmogony, the creation and renewal of the world, the "birth" of Tausi Malak ${ }^{7}$. According to one of the Yezidi cosmogonic myths, God created the world in the shape of an egg, but it was smooth, empty and covered with ice. God sent Tausi Malak to break the ice which covered the world so that Adam and Eve could live there. Tausi Malak broke the ice and brought spring to the world. Thus, according to popular interpretation, the colors of the eggs painted during Charshama Sor symbolize the different colors of nature. For example, green is the color of grass, and red and yellow are the colors of the Sun ${ }^{8}$. In the Middle East, the image of the peacock was perceived as an incarnation of the devil, as it was identified with a fallen angel that was exiled from Paradise. That is why the neighbors of the Yezidis very often identified them as "devil worshippers" " On the other hand, in the East, the peacock was also a symbol of beauty, majesty, wisdom and luxury. In India, the peacock was considered to be the symbol of the Sun, the immortal gods, and its feathers were associated with the allseeing eye ${ }^{10}$. The existence of such an element in the Yezidi religion can be explained by the contacts of Yezidism with different teachings in their historical homeland ${ }^{11}$. Yezidis venerate Tausi Malak through holy objects called Taus or $\sin \hat{\jmath} \bar{a} q^{12}$. There were $7 \sin \hat{\jmath} \bar{a} q s$ in the Yezidi community, Yezidis lost some $\sin \hat{\jmath} \bar{q} q$ during wars and massacres. One sinj̄a $q$ is now preserved in Armenia. In Iraq, once or several times a Year, qawals take the sinjāqs to Yezidi-inhabited villages, people come, bow, kiss it, and give some money. During the "Charshama Sor" feast, Yezidis perform religious rites at the shrine of Sheikh Adi and wash the $\operatorname{sinj} \bar{a} q$ in the holy spring (fountain) called $\mathbf{Z i m z i m}^{13}$. This spring is located in a cave $^{14}$. This cave is one of the most sacred Yezidi sites. When making a pilgrimage, believers go to that spring and wash their hands with its water. Foreigners are not allowed to go to Zimzim. Yezidis believe that the water and the stones in the cave heal diseases. There is a belief that if people go together to Zimzim, they will become siblings. This is why engaged young Yezidis are not allowed to go to Zimzim together There are different tales about the emergence of the Zimzim spring. In one religious hymn, there is the following story: forty nonYezidi sheikhs from Baghdad come to see the miracles of Sheikh Adi and have a

\footnotetext{
${ }^{7}$ Broka 2013: 88-90:

8 Uúnjui 2016: 243:

${ }^{9}$ Luke 1925: 14; 122-137; Joseph 1919: 89, 93, 98, 102; Empson 1928: 21-26, 93, 145, 203; Пушкин 1970: 248; Елисеев 1888: 59-74.

10 Трессидер 2001: 264; Амирбекян 1989: 67-70

${ }^{11}$ Sеe Аракелова 2006: 63-66.

12 The word $\sin \hat{j} \bar{q} q$ has Turkish origin and means "flag" or "symbol". The provinces of Ottoman Turkey were also called $\operatorname{sinj} \hat{a} q$ (Nicolaus 2008: 57-58). Probably the seven Yezidi $\sin \hat{\bar{a}} q$ symbolized the Yezidi-populated areas where those sanjaks were taken.

${ }_{13}^{13}$ Açıkyldız 2010: 108-109.

${ }^{14}$ There are also other holy springs in Yezidi beliefs. The worship of springs in Yezidism is partly borrowed from the Islamic religious tradition and partly from the ancient religions and local beliefs in the region. Such elements developed in a unique way in the Yezidi tradition.
} 
religious dispute with him. After a long discussion, the sheikhs want to perform ablution but there is no water. Sheikh Adi struck a rock with his rod, and Zimzim originated there ${ }^{15}$. In the Yezidi religion, the cult of Zimzim is a clear example of inheritance from the Islamic religious tradition. In Islam, a well called Zamzam is one of the holiest objects and pilgrimage sites. Zamzam is located in Saudi Arabia, in the territory of the Masjid al-Haram in Mecca. The name of Zamzam is related to Hagar and her son Ismail, who were left in the desert ${ }^{16}$. Zimzim is located in the Yezidis' main sanctuary and its origin is connected to the miracle of Sheikh Adi. Obviously, after the arrival of Sheikh Adi, the spring in the cave received the name Zamzam because the members of the Adawwia brotherhood tried to create their own Mecca in Lalish. According to the Yezidi tradition, the spring was called Zimzim because Sheikh Adi gave that name to the spring ${ }^{17}$. Thus, turning into a closed, ethno-confessional group, the Yezidy community developed its religious system and transformed many elements inherited from old Iranian religions, Islam, and local beliefs.

In Yezidi religious tradition, Wednesday is considered to be a holy day. In Lalish, Yezidi religious attendants put lamps or wicks on the stones and walls of holy places every Wednesday. According to one of the Yezidi religious hymns:

Go: Roja rukna dinê danînê şem û îne,

Şemîyê danîn esase,

Çarşemê birîn kirase. (Qewlê Şêx û Aqûb) ${ }^{18}$

It is said that the pillar of creation of the world was set on Wednesday and on Friday,

The foundation [of the world] was laid on Saturday,

The program was completed on Wednesday.

In the past, in some Yezidi inhabited villages of Armenia, people used to celebrate three Wednesdays as holidays during March. On the first Wednesday of March, each Yezidi family prepared food for the souls of their relatives and sent it to a neighbor's home. In the afternoon, people used to light a fire in the yard or on the roof and jump over it. People spent the second and third Wednesdays of March the same way. The first Wednesday of March was called Oxirčāršam, the second

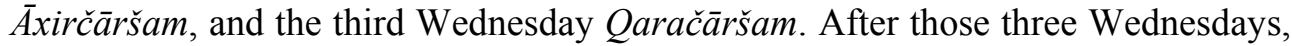
people celebrated the holiday called Çarşema serê Nîsanê (lit. "The Wednesday of the beginning of April") ${ }^{19}$. For a long time, the Yezidis of Armenia did not celebrate Charshama Sor as the Yezidis of Iraq do. Yezidis of Armenia did not paint eggs and did not visit holy places (because there were no sanctuaries in

\footnotetext{
15 Unupt|nцw, Uর্ৰjư 2010-2011, 17-18:

${ }^{16}$ Ислам: Энциклопедический словарь 1991: 75.

17 Unupt_nцu, Uর্̃juir 2010-2011, 19-20:

${ }^{18}$ Celîl, Celîl 1978: 45

${ }^{19}$ Eskerê Boyîk 2013a: 199, 200, 206.
} 
Armenia). After April 13, they used to celebrate Çarşema Serê Sale (lit. "the Wednesday of the beginning of the year" $)^{20}$. On that day they prepared a meal for the souls of their dead relatives and visited the cemetery.

This is mentioned in one Yezidi religious hymn:

Çarşema serê Nîsanê

Gul û çîçek hatin meydanê,

Tausî reîsê îmanê

Nîşan lê kir e

Bihar pê dixemile

Kesk û sor û spî û zer e. ${ }^{21}$

On the Wednesday during April

The flowers appeared,

Tausi Malak is the ruler of faith,

He gave a message,

Spring was decorated with different colors

Green, red, white and yellow.

After Yezidi sanctuaries were built in Armenia, many Yezidis started to celebrate Charshema Sor there the way their compatriots in Lalish do. Up till 2012, Yezidis in Armenia did not have unique Yezidi temples. Now they have two temples in Armenia built in the village called Aknalich in Armavir province. One of them was opened in 2012 (called "Zîyaret", lit. "pilgrimage site"), while another one was opened in 2019 (called "Quba heft merê dîwanê u Tawûsê Melek", lit. "the sanctuary of the seven holy men and Tausi Malak")

There is no doubt that the Yezidi Charshama Sor is a version of the Iranian Charshanbe Suri. An analysis of Charshama Sor reveals that the Yezidi tradition preserved Charshanbe Suri and its main symbols but endowed it with a new Yezidi interpretation. For example, the name of the holiday is translated "Red Wednesday". The color red has an important meaning in the Yezidi religion since it is associated with the name of one of the Yezidi saints - Sultān Ezzide Sōr (lit. "Red Sultan Yezid"). He is considered to be the forefather of the Yezidi people, and he keeps the seven layers of the land and seven layers of the sky (the fourteen layers of the Universe) in his hand. In folk tradition, he battled against the enemies of the Yezidi religion, protected the Yezidi community, and after his victory, he drank wine. Unlike Muslims, Yezidis are permitted to drink alcohol and this permission is associated with Sultan Yezid ${ }^{22}$.

Concerning the Iranian New Year - Nowruz (Kurdish: Navrōz, Nawrōz), the Yezidis who identify with the Kurdish identity celebrate it as the beginning of

\footnotetext{
${ }^{20}$ Açıkyıldız 2010: 108, 102; Kreyenbroek 1995: 151.

${ }^{21}$ Eskerê Boyîk 2013b: 21

22 Uúnjuน 2016: 35:
} 
Spring, new life, the New Year, and freedom ${ }^{23}$. Navroz began to spread among some Yezidis living in Armenia in the 1990s in the result of the propaganda of Kurdistan Workers' Party (PKK). Navroz is mostly celebrated by Yezidis who identify with the Kurdish identity and share some of the ideas of the Kurdistan Workers' Party (PKK). The PKK continues to celebrate Navroz as a symbol of the unity, rebirth, victory and freedom for all Kurds ${ }^{24}$. Yezidis who do not accept Kurdish identity do not celebrate Navroz because they consider it to be a Kurdish holiday and sometimes even mistakenly consider it to be of Islamic origin.

This analysis of Charshama Sor once again proves that some religious realities of Iranian origin have evolved in Yezidism and currently have unique interpretations from the Yezidi perspective. Thus, we can say that holidays of Islamic origin have developed in a unique way in the closed Yezidi community; it generated and developed rituals and interpretations specific to Yezidism.

\section{BIBLIOGRAPHY}

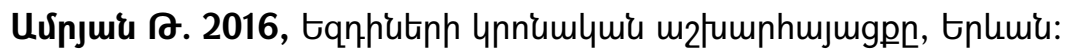

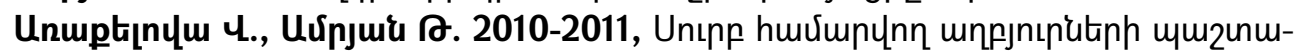

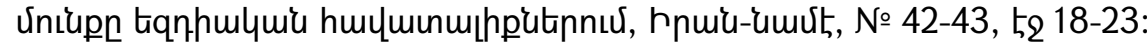

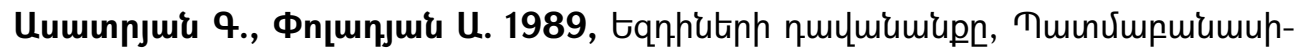
nulyuiu huiuntu, № 4, tplumiu, to 131-150:

Амирбекян Р. 1989: К вопросу о некоторых зооморфных символах в искусстве Востока, Историко-филологический журнал, № 1, Ереван, сс. 65-78.

Аракелова В. 2006: К истории формирования езидской общины, Иран-намэ № 4, Ереван, сс. 63-66.

Елисеев А. 1888: Среди поклонников дьявола (Очерки верования езидов), Северный вестник, N1, том 1, Санкт-Петербург.

Ислам, Энциклопедический словарь, 1991, Коллектив авторов, ред. Негря Л., Москва.

Пушкин А. 1970: Путешествие в Арзрум во время похода 1829 года, сс. 211-268 // Собрание сочинений, том 8 , Москва.

Трессидер Дж. 2001: Словарь символов, Москва.

Açıyıldız B. 2010: The Yezidis. The History of a Community, Culture and Religion, London.

Alison F. 2013: Iranian fire-jumping festival delights Berkeley residents, The Daily Californian, March 13, https://www.dailycal.org/2013/03/13/persian-fire-jumpingfestival-delights-berkeley-residents/ (accessed 06.11.2021).

Arakelova V 2005: Sultan Ezid in the Yezidi Religion: Genesis of the Character, Paper read at the $2^{\text {nd }}$ ASPS Convention held in Yerevan, April 2004, Study of Persionnate Societies, Vol. 3, New Dehli, pp. 198-202.

\footnotetext{
${ }^{23}$ Eskerê Boyîk 2013b: 20.

${ }^{24}$ Gunes 2012: 95-96.
} 
Arakelova V. 2010: Ethno-Religious Communities: To the Problem of Identity Markers, Iran and the Caucasus, Vol.14, Leiden, pp. 1-18.

Arakelova V. 2004: Notes on the Yezidi Religious Syncretism, Iran and the Caucasus, Vol. 8.1, Leiden, pp. 19-29.

Asatrian G., Arakelova V. 2003: Malak-Tawus: The Peacock Angel of the Yezidis, Iran and the Caucasus, Vol. 7.1-2, Leiden, pp. 1-36.

Baratzadeh E. 2021: Traditions of Chaharshanbe Suri: Jumping Fire and Wish-Granting Nuts, Kitchen Starts, https://kitchenstarts.com/chaharshanbe-suri-persian-firefestival/ (accessed 06.11.2021).

Gunes C. 2021: The Kurdish National Movement in Turkey: From Protest to Resistance, New York.

Empson R. 1928: The Cult of the Peacock Angel, London.

Joseph I. 1919: Devil Worship: The Sacred Books and Traditions of the Yezidis, Boston.

Kharatyan H. 2009: The Culture of the Holiday in Armenia, Yerevan.

Kreyenbroek Ph. 1995: Yezidism: Its Background, Observances and Textual Tradition, New York.

Luke H. 1925, Mosul and its Minorities, London.

Nasri N. 2019, With red flowers, Yezidis prepare to welcome the New Year, https://www.rudaw.net/english/kurdistan/160420191 (accessed 02.11.2021).

Nicolaus P. 2008: The Lost Sanjaq, Iran and the Caucasus, Vol. 12. 2, Leiden, pp. 217-253.

Parry O. H. 1895: Six Months in a Syrian Monastery, London.

Raghebi K. 2021: Charshanbeh Soori; a Preparation for Nowruz, https://www.visitouriran.com/blog/charshanbeh-soori-a-preparation-for-nowruz/ (accessed 04.11.2021)

Rodziewicz A. 2016: And the Pearl Became an Egg: The Yezidi Red Wednesday and Its Cosmogonic Background, Iran and the Caucasus, Vol. 20, No. 3/4, Special Issue, Leiden, pp. 347-367.

Eskerê Boyîk 2013: Çarşema Hesava // Cejnên Ezidîyan, Kurdistan-Hewlêr, rûp. 198-209 (in Kurdish).

Eskerê Boyîk 2013: Cejnên kurdên êzdî // Cejnên Ezidîyan, Kurdistan-Hewlêr, rûp. 10-25 (in Kurdish).

Boyce M. 1977, A Persian Stronghold of Zoroastrianism, Oxford (in Kurdish).

Celîl O., Celîl C. 1978: Zargotina Kurda, II, Moscow (in Kurdish).

Broka H. 2013: Cejnen êzdîyan di navbera "dema Xwedê" û "dema mirov da"//Cejnên Ezidîyan, Kurdistan-Hewlêr, rûp. 80-102 (in Kurdish).

Tereza Amryan

Yerevan State University amryantereza@ysu.am 


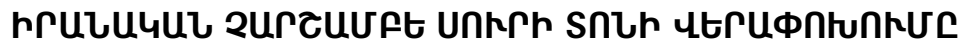

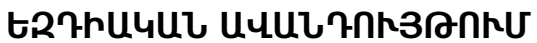

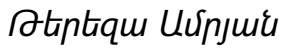

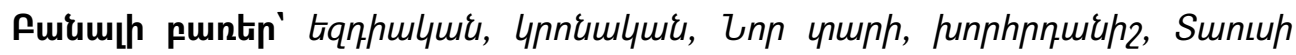

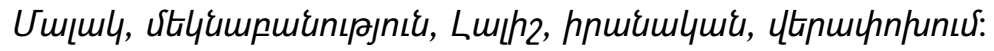

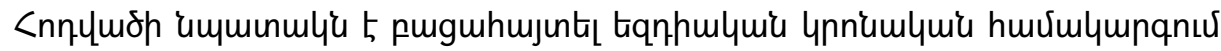

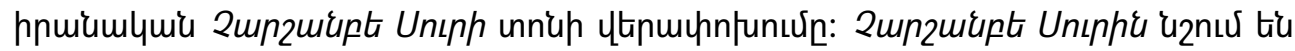

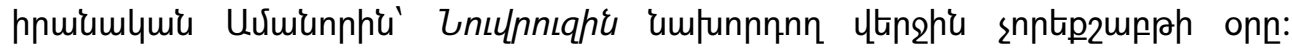

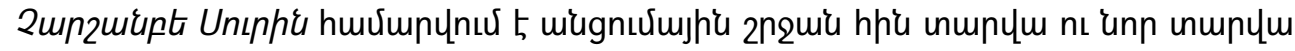

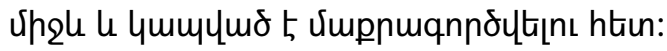

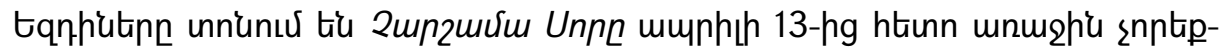

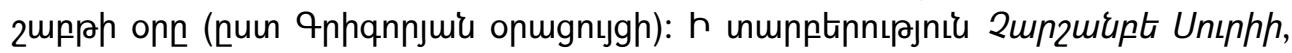

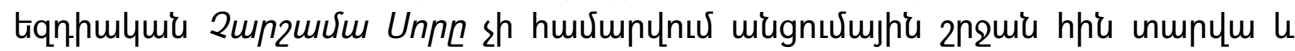

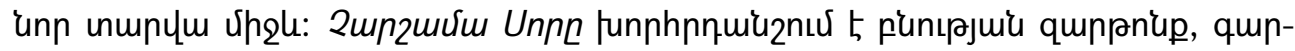

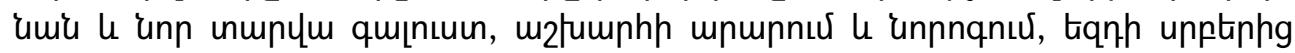
vituh' Sunnup Umqulh «duniun»:

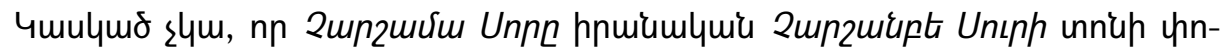

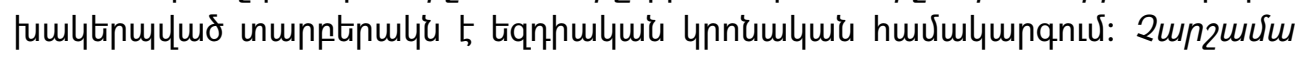

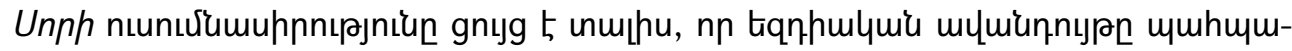

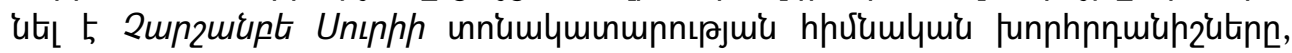

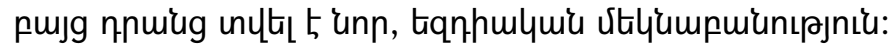

